\title{
Impacts of chronic and increasing lipopolysaccharide exposure on production and reproductive parameters in lactating Holstein dairy cows
}

\author{
M. J. Dickson, ${ }^{1}$ S. K. Kvidera, ${ }^{1}$ E. A. Horst, ${ }^{1}$ C. E. Wiley, ${ }^{1}$ E. J. Mayorga, ${ }^{1}$ J. Ydstie, ${ }^{1}$ G. A. Perry, ${ }^{2}$ \\ L. H. Baumgard, ${ }^{1}$ and A. F. Keating ${ }^{1 *}$ \\ ${ }^{1}$ Department of Animal Science, lowa State University, Ames 50011 \\ ${ }^{2}$ Department of Animal Science, South Dakota State University, Brookings 57006
}

\section{ABSTRACT}

Lipopolysaccharide (LPS) administration causes immunoactivation, which negatively affects production and fertility, but experimental exposure via an acute bolus is unlikely to resemble natural infections. Thus, the objectives were to characterize effects of chronic endotoxemia on production parameters and follicular development in estrous-synchronized lactating cows. Eleven Holstein cows $(169 \pm 20 \mathrm{~d}$ in milk; $681 \pm 16 \mathrm{~kg}$ of body weight) were acclimated to their environmental surroundings for $3 \mathrm{~d}$ and then enrolled in 2 experimental periods (P). During P1 (3 d) cows consumed feed ad libitum and baseline samples were obtained. During P2 ( $7 \mathrm{~d})$, cows were assigned to continuous infusion of either (1) saline-infused and pair-fed (CON-PF; $40 \mathrm{~mL} / \mathrm{h}$ of saline i.v.; $\mathrm{n}=5$ ) or (2) LPS infused and ad libitum fed (LPS-AL; Escherichia coli O55:B5; 0.017, 0.020, 0.026, $0.036,0.055,0.088$, and $0.148 \mu \mathrm{g} / \mathrm{kg}$ of body weight $/ \mathrm{h}$ i.v. on $\mathrm{d} 1$ to 7 , respectively; $\mathrm{n}=6$ ). Controls were pair-fed to the LPS-AL group to eliminate confounding effects of dissimilar nutrient intake. Infusing LPS temporally caused mild hyperthermia on d 1 to $3\left(+0.49^{\circ} \mathrm{C}\right)$ relative to baseline. Dry matter intake of LPS-AL cows decreased $(28 \%)$ on d 1 of P2, then progressively returned to baseline. Relative to baseline, milk yield from LPS-AL cows was decreased on d 1 of P2 (12\%). No treatment differences were observed in milk yield during P2. Follicular growth, dominant follicle size, serum progesterone (P4), and follicular $\mathrm{P} 4$ and $17 \beta$-estradiol concentrations were similar between treatments. Serum $17 \beta$-estradiol tended to increase $(115 \%)$ and serum amyloid A and LPS-binding protein were increased (118 and $40 \%$, respectively) in LPS-AL relative to CON-PF cows. Compared with CON-PF, neutrophils in LPS-AL cows were initially increased (45\%), then gradually de-

Received August 31, 2018.

Accepted December 5, 2018.

*Corresponding author: akeating@iastate.edu creased. In contrast, monocytes were initially decreased $(40 \%)$ and progressively increased with time in the LPSAL cows. Hepatic mRNA abundance of cytochrome P450 family 2 subfamily $\mathrm{C}(C Y P 2 C)$ or $C Y P 3 A$ was not affected by LPS, nor was there a treatment effect on toll-like receptor 4 or $L B P$; however, acyloxyacyl hydrolase and RELA subunit of nuclear factor kappa $\mathrm{B}$ tended to be increased in LPS-AL cows. These data suggest lactating dairy cows become tolerant to chronic and exponentially increasing LPS infusion in terms of production and reproductive parameters.

Key words: lipopolysaccharide, immunoactivation, ovary, tolerance

\section{INTRODUCTION}

Inflammation is detrimental to productivity and arises from a myriad of physiological insults, including both biotic and abiotic stress. Immunoactivation results from common on-farm issues such as ruminal acidosis, mastitis, metritis, heat stress, and parturition (Gozho et al., 2005; Ballou, 2012; Baumgard and Rhoads, 2013; Sheldon et al., 2014). Although these stressors have differing etiologies, they often result in increased circulating LPS, an immunogenic pathogen-associated molecular pattern (PAMP), which acts through the toll-like receptor 4 (TLR4) pathway. Activation of TLR4 initiates a signaling cascade culminating in nuclear translocation of the p65 subunit of nuclear factor kappa B (NF $\mathbf{k B})$ and subsequent inflammatory cytokine production (Chow et al., 1999; Lu et al., 2008). Lipopolysaccharide also stimulates reactive oxygen species (ROS) production (Rietschel et al., 1994) and LPS and ROS induce vascular endothelial growth factor (VEGF; Chua et al., 1998; Matsushita et al., 1999). Superoxide dismutase 1 (SOD1) represents a cellular defense against ROS (McCord and Fridovich, 1969; Weisiger and Fridovich, 1973).

The systemic response to LPS has been well documented and is characterized by increased production of 
acute phase proteins [e.g., LPS-binding protein $(\mathbf{L B P})$ and serum amyloid A (SAA)], decreased productivity (e.g., milk yield, growth), hyperthermia, metabolic dysfunction, and impaired reproduction (Lohuis et al., 1988; Giri et al., 1990; Lochmiller and Deerenberg, 2000; Waldron et al., 2003; Bidne et al., 2018a). Also, hepatic acyloxyacyl hydrolase (AOAH) deacylates LPS, rendering it unable to elicit an immune response (Munford and Hall, 1986).

Ironically, inflammation is integral to normal reproductive function (Espey, 1980; Richards et al., 2008). In fact, administering nonsteroidal anti-inflammatory drugs immediately precalving and immediately postcalving increases the incidence of stillbirths and retained placenta, respectively (Newby et al., 2017), but this is not always consistent (Newby et al., 2014). However, excess inflammation can also be detrimental to fertility. For example, metritic cows (Dohmen et al., 2000; Mateus et al., 2003) are less fertile (Sheldon et al., 2014), likely because LPS alters steroid signaling (Kujjo et al., 1995; Lavon et al., 2008), compromises caprine luteal function (Fredriksson et al., 1985; Gilbert et al., 1990), and causes abortion (Skarnes and Harper, 1972; Giri et al., 1990). Estrogen sulfotransferase (SULT1E1) is a transcriptional target of phosphorylated nuclear factor kappa B, and in mice, LPS induces SULT1E1 (Chai et al., 2015). Lipopolysaccharide also causes hyperinsulinemia (Waldron et al., 2003) and progesterone (P4) metabolism enzymes, cytochrome P450 family 2 subfamily C (CYP2C) and cytochrome P450 family 3 subfamily A (CYP3A), are altered in dairy cows by insulin (Lemley et al., 2008). Additionally, some studies seem to indicate that the deleterious effects of LPS may linger following infection resolution (Fonseca et al., 1983; Hudson et al., 2012) and represent a long-term economic burden to the global dairy industry (Sheldon et al., 2009).

The reproductive and inflammatory response to acute LPS exposure has been well chronicled (Giri et al., 1990; Lüttgenau et al., 2016). However, natural infection likely causes a more persistent and dynamic LPS exposure, reflective of bacterial overgrowth and proliferation. Short-term (4 h), but continuous, LPS administration prompts a less aggressive but more sustained release of inflammatory mediators, presumably a more accurate model of chronic inflammation than an acute bolus (Taudorf et al., 2007). However, the response is temporally dependent as repeated or continuous exposure to a constant amount of endotoxin creates tolerance in numerous cell lines and in multiple species (Beeson, 1947; West and Heagy, 2002). In an effort to create a more physiologically relevant LPS exposure paradigm and to avoid the aforementioned well-described tolerant phenotype, we continuously i.v. infused increasing quantities of LPS into healthy lactating cows to characterize the effects of chronic endotoxemia on production, inflammation, and reproductive indices. We hypothesized that continuous and exponentially increasing LPS exposure would stimulate a sustained inflammatory response and negatively affect reproductive and production parameters.

\section{MATERIALS AND METHODS}

\section{Animals and Experimental Design}

All procedures were approved (\#8202) by the Institutional Animal Care and Use Committee at Iowa State University. Eleven lactating Holstein cows (mean \pm SEM; $169 \pm 20$ DIM; $681 \pm 16 \mathrm{~kg}$ of BW; parity 3.1 $\pm 0.4)$ were housed in individual box-stalls $(4.57 \times 4.57$ $\mathrm{m})$ at the Iowa State University dairy farm. A modified Ovsynch protocol was used to align estrous cyclicity. Two weeks before study initiation, ovarian status was evaluated using transrectal ultrasonography (Ibex Pro, E. I. Medical Imaging, Loveland, CO) and dinoprost (5 mL, Lutalyse Zoetis Animal Health, Parsippany, NJ) was administered i.m. to lyse any functional luteal tissue. During the experimental phase, cows received a second dose of dinoprost $(5 \mathrm{~mL})$ on $\mathrm{d} 2$ of the acclimation period, followed by gonadorelin (i.m., $2 \mathrm{~mL}$; Factrel Zoetis Animal Health, Parsippany, NJ) administered $60 \mathrm{~h}$ after dinoprost injection. Ovaries were evaluated 12 and $24 \mathrm{~h}$ after gonadorelin injection via ultrasound to monitor ovulation. The purpose of the synchronization was to ensure that all cows had a metestrous/early diestrous corpus luteum and a first wave dominant follicle at similar stages of development during the experimental infusion treatments.

Cows were allowed $3 \mathrm{~d}$ to acclimate to housing conditions during which bilateral jugular catheters (to obtain blood and infuse simultaneously) were inserted. Following acclimation, cows were enrolled in 2 experimental periods $(\mathbf{P})$. During P1 (3 d), baseline data were collected for covariate analysis. Period 2 lasted $7 \mathrm{~d}$ during which cows received 1 of 2 treatments: (1) saline-infused and pair-fed (CON-PF; $40 \mathrm{~mL} / \mathrm{h}$ sterile saline i.v.; $\mathrm{n}$ $=5$ ) or (2) LPS infused and ad libitum fed (LPS-AL; $0.017,0.020,0.026,0.036,0.055,0.088$, and $0.148 \mu \mathrm{g}$ of LPS $/ \mathrm{kg}$ of $\mathrm{BW} / \mathrm{h}$ i.v. on $\mathrm{d} 1$ to 7 , respectively; $\mathrm{n}=$ 6). Lipopolysaccharide was administered by a constant i.v. infusion at a known and adjustable rate utilizing a modular pump (Deltec 3000, Deltec Inc., St. Paul, $\mathrm{MN}$ ). The LPS dose was increased every day (Figure 1A) and calculated based on BW obtained during the acclimation period. The LPS stock solution (Escherichia coli O55:B5, L2880, Sigma Aldrich, St. Louis, MO) was prepared at a concentration of $300 \mu \mathrm{g} / \mathrm{mL}$, passed 
through a $0.2-\mu \mathrm{m}$ sterile syringe filter (Thermo Fisher Scientific, Waltham, MA), and stored in a sterile glass bottle $24 \mathrm{~h}$ before P2 as we have previously described (Kvidera et al., 2017; Horst et al., 2018). The LPS dose and increasing daily infusion rate were selected based on data from a similar experimental design utilizing pigs (Bidne et al., 2018b; Huntley et al., 2018). Each day, the amount of stock solution needed for each cow's daily dose was injected into a 1-L bottle of sterile saline. The i.v. infusion system was incubated overnight with LPS solution $(3 \mu \mathrm{g} / \mathrm{mL})$ before infusion onset to saturate LPS binding sites in the Tygon tubing (SaintGobain ND 100-80, Akron, OH).

Control cows were pair-fed (PF) to the LPS-treated cows to avoid confounding effects of dissimilar nutrient intake as previously described (Wheelock et al., 2010). All cows had ad libitum access to water, were fed a TMR once daily at $0800 \mathrm{~h}$, and orts were recorded before feeding. The TMR was formulated by Dynamic Nutrition Systems (Pierz, MN) to meet or exceed the predicted requirements of energy, protein, minerals, and vitamins (NRC, 2001; Table 1). Reduced daily feed intake by LPS-AL cows during P2 was determined as a percentage of their mean daily ad libitum intake during P1. To facilitate space constraints and the pair-feeding procedures, control cows were $9 \mathrm{~d}$ behind LPS-infused cows in the experimental protocol. Throughout the study, cows were milked twice daily (0600 and $1800 \mathrm{~h}$ ) and yields were recorded at each milking. A milk sample for composition was obtained daily at the $0600 \mathrm{~h}$ milking and stored at $4^{\circ} \mathrm{C}$ with a preservative (bronopol tablet; D \& F Control System, San Ramon, CA) until analysis by Dairy Lab Services (Dubuque, IA) using infrared analysis equipment and procedures approved by AOAC International (1995).

Respiration rate $(\mathbf{R R})$, heart rate (HR), and rectal temperature $(\mathbf{T r})$ were recorded twice daily at 0600 and $1800 \mathrm{~h}$. Respiration rate and HR were measured as flank movement and beats per $15 \mathrm{~s}$, respectively, and later configured to breaths per minute and beats per minute (bpm). Rectal temperatures were measured using a digital thermometer (GLA Agricultural Electronics M700, San Luis Obispo, CA). Serum and plasma samples were collected daily at $0600 \mathrm{~h}$ during both $\mathrm{P} 1$ and P2 using an empty glass tube and a tube containing EDTA as the anticoagulant (K2 EDTA, Becton, Dickinson and Company, Franklin Lakes, NJ), respectively. Before centrifugation, serum samples were allowed to clot for $30 \mathrm{~min}$ at room temperature. Serum and plasma were harvested following centrifugation at $1,500 \times g$ for $15 \mathrm{~min}$ at $4^{\circ} \mathrm{C}$, and were subsequently frozen at $-20^{\circ} \mathrm{C}$ until analysis. Samples for complete blood count analysis were collected twice daily (0600 and $1800 \mathrm{~h}, \mathrm{~K} 2$ EDTA, Becton, Dickinson and Company) during P2. A blood sample was collected from the i.v. catheter and stored at $4^{\circ} \mathrm{C}$ for approximately $12 \mathrm{~h}$ before submission to the Iowa State University Department of Veterinary Pathology for hematological analysis (ADVIA 2120/2120i Hematology System) to assess the numbers of neutrophils, lymphocytes, and monocytes present.

\section{Tissue Collection}

Liver, skeletal muscle, and tailhead subcutaneous adipose tissue biopsies were collected from all animals on $\mathrm{d} 7$ of P2 following the $0600 \mathrm{~h}$ milking. Briefly, biopsy sites were shaved, scrubbed with betadine, and sprayed with $70 \%$ alcohol. For liver collection, the area was locally anesthetized using $2 \%$ lidocaine (MWI Veterinary Supply Co., Glendale, AZ) before performing a percutaneous biopsy with a trocar. Before collecting adipose and muscle biopsies, a caudal epidural (25 $\mathrm{mg}$ of xylazine and $100 \mathrm{mg}$ of lidocaine hydrochloride) was administered. Tailhead subcutaneous adipose tissue was collected as previously described (Leury et al., 2003). In brief, a 2 to $3 \mathrm{~cm}$ incision was made between the tailhead and the tuber ischia and adipose tissue was collected. For skeletal muscle collection, an incision $(\sim 5 \mathrm{~cm})$ was made in the skin of the hind limb overlying semitendinosus muscle, and a sterile biopsy punch ( $8 \mathrm{~mm}$, Miltex Inc., York, PA) was used for collecting a tissue core as previously described (Xie et al., 2016). Following collection, adipose and muscle biopsy sites were sutured, cleaned with $70 \%$ isopropanol, and disinfected with an aerosol bandage (AluShield, Neogen Corp., Lexington, KY). All samples were snap frozen in liquid nitrogen and stored at $-80^{\circ} \mathrm{C}$ until analysis.

\section{Reproductive Parameters}

Throughout P2, ovaries were assessed by ultrasound scanning every morning at $0600 \mathrm{~h}( \pm 1 \mathrm{~h})$ to track follicular growth. A minimum of 2 pictures per structure were recorded daily to analyze follicular growth and presence of corpus lutea. On d 7 of P2 the dominant follicle from each animal was aspirated to collect follicular fluid using transvaginal ultrasound guided aspiration (SSD-900V, Aloka Co. Ltd., Tokyo, Japan) with an 18-gauge needle (DI-0207-10, Partnar Animal Health, Port Huron, MI). The sample was collected through pyrogen-free tubing (Macrobore Extension Set, 30 inch with Option-lok, non-DEHP; 12656-28, Hospira, Lake Forest, IL) and stored in pyrogen-free micro-centrifuge tubes. Sterile PBS ( $4 \mathrm{~mL}$ ) was used to flush the tubing to ensure collection of the entire sample. Follicular fluid 


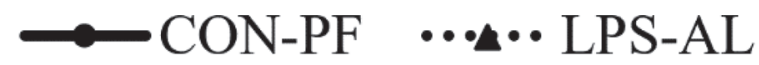

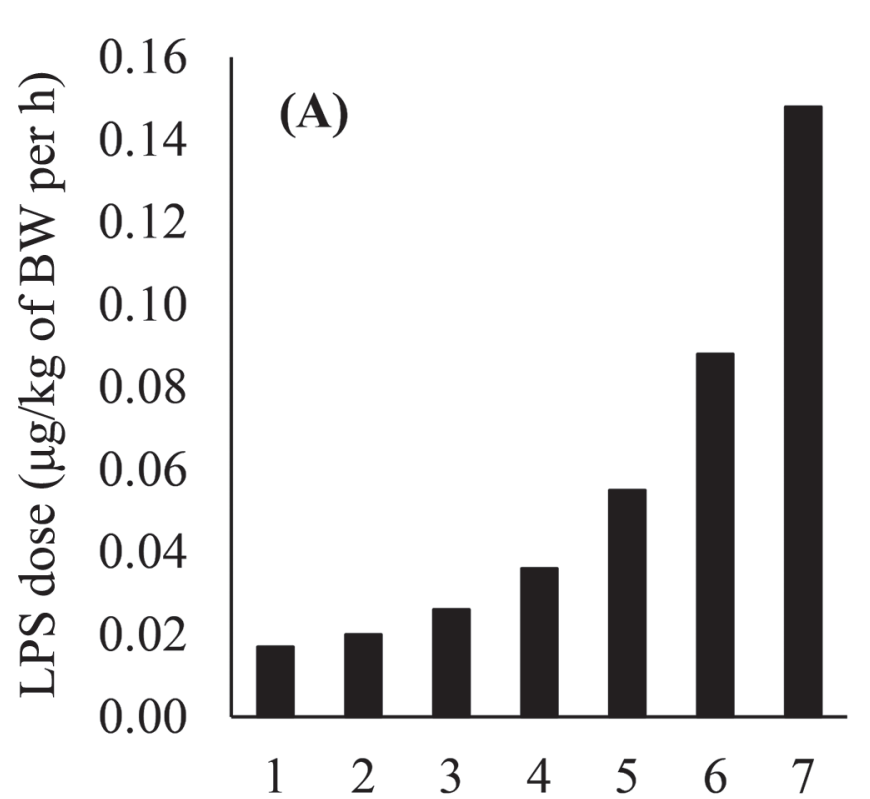

Day of infusion

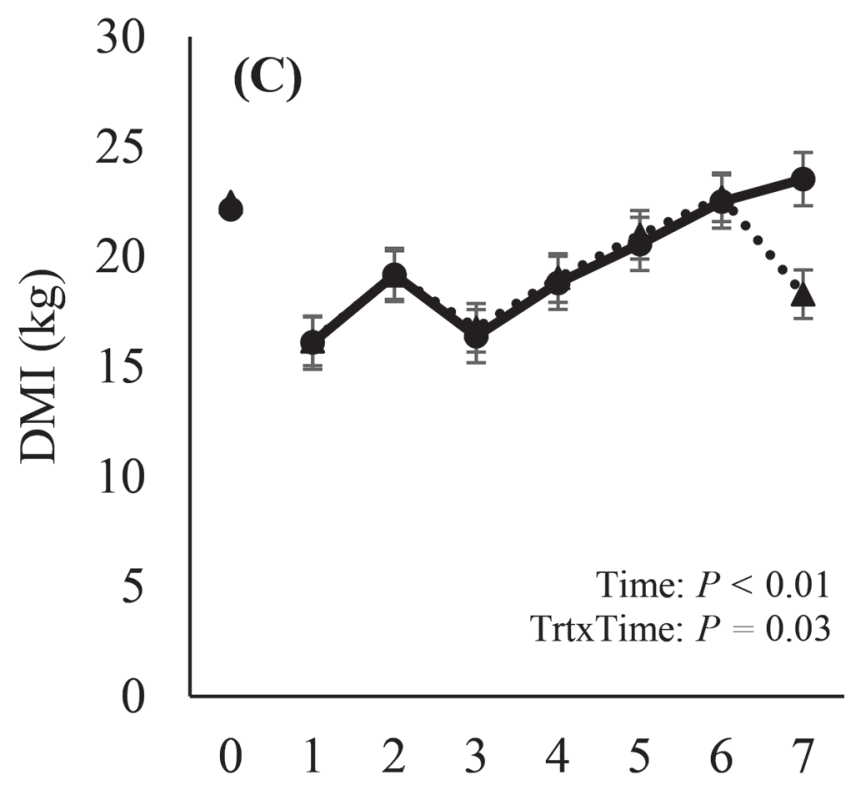

Day relative to infusion start
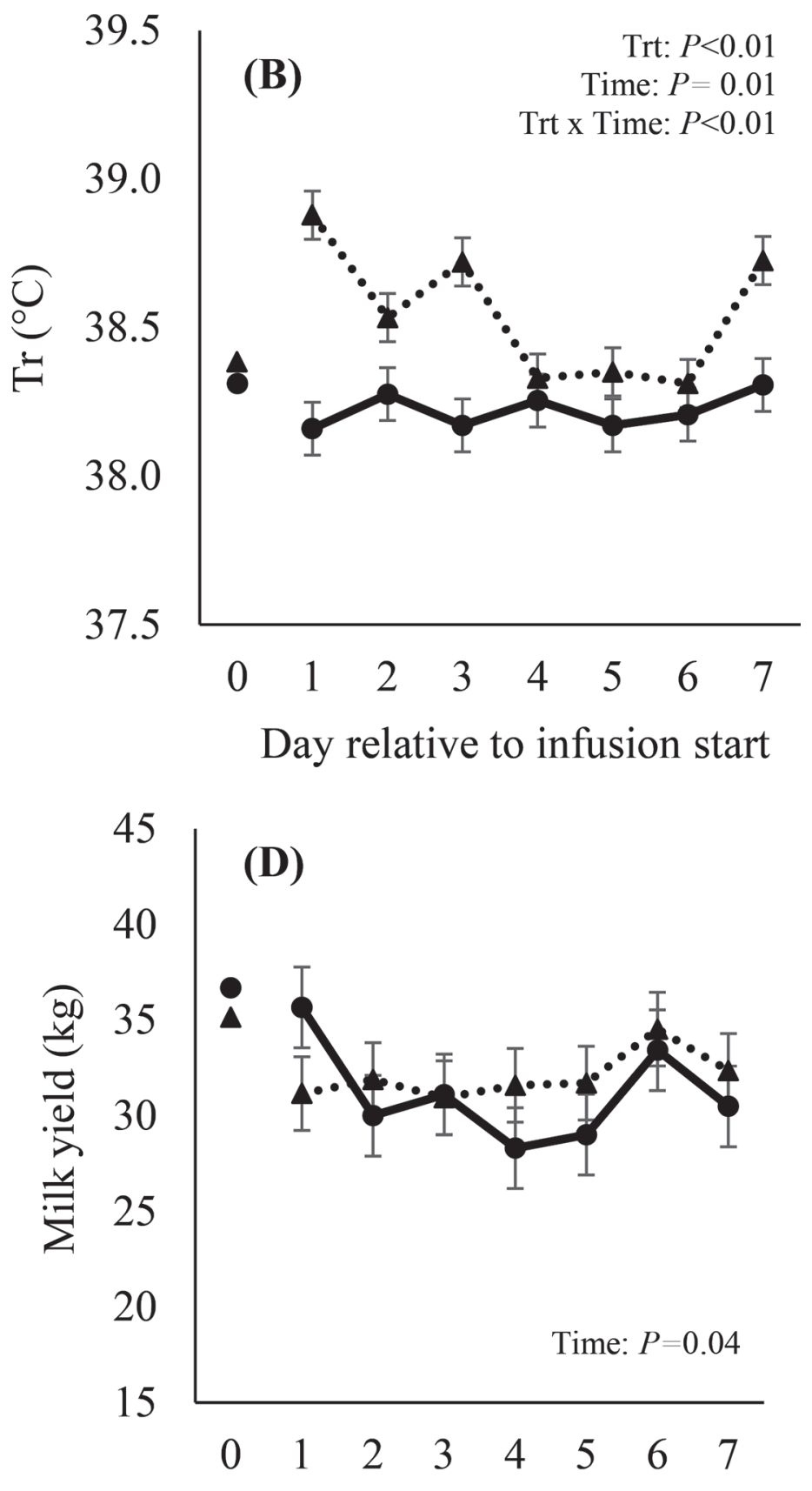

Day relative to infusion start

Figure 1. Effects of chronic and increasing exposure of LPS (A) on rectal temperature (Tr; B), DMI (C), and milk yield (D). Treatments include saline infused and pair fed (CON-PF) and LPS infused with ad libitum feed intake (LPS-AL). Results are expressed as LSM \pm SEM. Embedded $P$-values represent differences between CON-PF and LPS-AL during period 2. Trt $=$ treatment. 
Table 1. Ingredients and composition of $\operatorname{diet}^{1}$

\begin{tabular}{lc}
\hline Item (\% of DM, unless noted) & Value $^{2}$ \\
\hline Ingredient & \\
Corn silage & 32.53 \\
Corn gluten feed & 19.61 \\
Alfalfa hay & 12.80 \\
Ground corn & 8.76 \\
Cottonseed & 5.10 \\
Molasses & 2.43 \\
Expeller soybean meal & 0.89 \\
Soybean meal & 4.75 \\
CP mix & 11.09 \\
Straw & 2.04 \\
Chemical analysis & \\
Starch & 22.86 \\
CP & 16.95 \\
NDF & 31.09 \\
ADF & 20.28 \\
NE & 1.61 \\
\hline
\end{tabular}

${ }^{1}$ Values represent an average of ration nutrient summary reports collected throughout the trial. Diet moisture averaged $52.49 \%$.

${ }^{2}$ Average nutrient levels: $5.02 \%$ fat, $0.91 \% \mathrm{Ca}, 0.47 \% \mathrm{P}, 0.36 \% \mathrm{Mg}$, $0.23 \% \mathrm{~S}, 1.32 \% \mathrm{~K}, 0.53 \% \mathrm{Na}, 0.59 \% \mathrm{Cl}, 69.39 \mathrm{mg} / \mathrm{kg}$ of Zn, $38.09 \mathrm{mg} /$ $\mathrm{kg}$ of $\mathrm{Mn}, 3.02 \mathrm{mg} / \mathrm{kg}$ of $\mathrm{Fe}, 11.61 \mathrm{mg} / \mathrm{kg}$ of $\mathrm{Cu}, 0.65 \mathrm{mg} / \mathrm{kg}$ of Co, $0.28 \mathrm{mg} / \mathrm{kg}$ of Se, $0.65 \mathrm{mg} / \mathrm{kg}$ of I, $6,005.6 \mathrm{IU} / \mathrm{kg}$ of vitamin A, 477.9 $\mathrm{IU} / \mathrm{kg}$ of vitamin $\mathrm{D}$, and $15.7 \mathrm{IU} / \mathrm{kg}$ of vitamin $\mathrm{E}$.

was transported on ice to the laboratory where it was centrifuged for $10 \mathrm{~min}$ at $10,621 \times g$ for $15 \mathrm{~min}$ at $4^{\circ} \mathrm{C}$. The supernatant was stored at $-80^{\circ} \mathrm{C}$.

\section{RNA Isolation and Quantitative Reverse- Transcription PCR}

Liver samples were processed for RNA isolation and total RNA was extracted using an RNeasy Mini kit according to the manufacturer's instructions (Qiagen 74004), including on-column DNase treatment. RNA was eluted with $20 \mu \mathrm{L}$ of RNase-free water and concentration determined using an ND-1000 spectrophotometer $(\lambda=260 / 280 \mathrm{~nm}$; NanoDrop Technologies Inc.). Total RNA was reverse transcribed into cDNA using a Superscript III system (Thermo Fisher Scientific) before PCR. For reverse-transcription PCR, all samples were run in triplicate on an Eppendorf Mastercycler and the amplification protocol consisted of 40 cycles of denaturating at $95^{\circ} \mathrm{C}$ for $15 \mathrm{~s}$, annealing at $58^{\circ} \mathrm{C}$ for 15 s, and extension at $68^{\circ} \mathrm{C}$ for $20 \mathrm{~s}$. Primers were prepared by the Iowa State University DNA facility (Ames). Sequences for TLR 4, REL associated protein of NFKB $(R E L A)$, acyloxyacyl hydrolase $(A O A H)$, and $L B P$ were designed via NCBI primer blast (https://www.ncbi.nlm .nih.gov/tools/primer-blast/), all spanned at least 1 exon junction, and are detailed in Table 2. Sequences for cytochrome $\mathrm{P} 450$ family 2 subfamily $\mathrm{C}(C Y P 2 C)$, cytochrome P450 family 3 subfamily A (CYP3A), and ribosomal protein 15 (RPS15) were from McCracken et al. (2015). Each set of reactions was performed to include negative controls of water only, as well as cDNA with Mastermix (Thermo Fisher Scientific) and omission of primers. The delta cycle threshold $(\mathbf{C t})$ value [gene of interest - RPS15 (reference gene)] was calculated for each sample, then the highest delta $\mathrm{Ct}$ value (within the control group) was chosen and set as equal to zero. The delta Ct value (controls and treated) for each sample was then subtracted from the highest control value. Fold change was calculated as 2 to the power of each normalized delta $\mathrm{Ct}$ value. Each fold change value was then divided by the average of the control fold change to normalize controls to one. Analysis was performed on samples collected at the end of P1 and P2 and the delta $\mathrm{Ct}$ values of the mRNA abundance from $\mathrm{P} 1$ to use as a covariate in the P2 analysis.

\section{Protein Extraction and Western Blotting}

The AOAH was measured in liver, skeletal muscle, and adipose tissues, and VEGF and SOD1 were quantified in the liver. Tissue samples were immersed in tissue lysis buffer (Trition-x-100, HEPES, NaCl, glycerol, NaF, EDTA, SDS) containing protease and phosphatase inhibitors (Halt Protease and Phosphatase SingleUse Inhibitor Cocktail 100x; 78442) and subjected to centrifugation $\left(1,500 \times g\right.$ for 15 min at $\left.4^{\circ} \mathrm{C}\right)$. Protein content of the supernatant was quantified using a bicinchoninic acid assay. Protein extract was mixed with Laemmli buffer, $\beta$-mercaptoethanol, and water and heated at $95^{\circ} \mathrm{C}$ for $5 \mathrm{~min}$. Samples were stored at $-20^{\circ} \mathrm{C}$ until use. Fixed amounts of protein were loaded onto pre-cast SDS PAGE gels and transferred onto

Table 2. Primer sequences used for gene amplification

\begin{tabular}{llll}
\hline Gene & Forward primer sequence $\left(5^{\prime}-3^{\prime}\right)$ & Reverse primer sequence $\left(5^{\prime}-3^{\prime}\right)$ & Accession no. \\
\hline RPS15 & ATCATTCTACCCGAGATGGT & TGCTTCACGGGCTTGTAAGT & NM_001024541.2 \\
TLR4 & GACCCTTGCGTACAGGTTGT & GCTGGAGAAGTTATGGCTGC & NM_174198.6 \\
RELA & CAACCCCTTCCAAGTTCCCA & CCCAGAGTTCCGATTCACCC & NM_001080242.2 \\
AOAH & ACACTTGAGAAGGCCAGACAG & CCGCAGTGTTGGAAATCAC & NM_001078096.2 \\
LBP & TGACGTGATTCCGCCTGATT & CCATCTGGGCAGCTGTAGAC & NM_001038674.2 \\
CYP2C & TCAGCAGGAAAAAGAGTTTGTGT & CTCACAGAAGGGTGGAATAGAGA & NM_001109792.2 \\
CYP3A & TCGATCCCTTTCTTCTCGCAG & AAGTCCACACGTGGCTTTTG & NM_001099367.1 \\
\hline
\end{tabular}


nitrocellulose membranes (iBLOT, Invitrogen, Carlsbad, CA). Verification of equal loading was determined using a Ponceau S stain. Membranes were blocked for a minimum of $1 \mathrm{~h}$ in $5 \%$ BSA in PBS with Tween 20 (PBST) and incubated in diluted $(5 \% \mathrm{BSA} / \mathrm{PBST}$ or PBST only) primary antibody at $4^{\circ} \mathrm{C}$ overnight. Primary antibodies used were directed against SULT1E1 (H-40; 1:200; SC-292049, Santa Cruz Biotechnologies, Santa Cruz, CA), superoxide dismutase (SOD1; 1:1,000; NB1-31204, Novus Biologicals, Littleton, CO), VEGF (1:1,000; NB100-648, Novus Biologicals), and AOAH Q-13 (1:500; 163694, Santa Cruz Biotechnologies). After primary incubation, membranes were washed 3 times in PBST. Membranes were incubated in secondary antibody (anti-mouse IgG, HRP-linked 7076P2, anti-rabbit IgG-HRP 7074P2; Cell Signaling Technology, Danvers, MA) for $1 \mathrm{~h}$ at room temperature, followed by 3 washes in PBST. Enhanced chemiluminescence (Signal Fire, Cell Signaling 6883) substrate was applied to the membrane in the dark and then imaged using a ChemiImager 5500 (Alpha Innotech, San Leandro, CA) with AlphaEaseFC software (v3.03 Alpha Innotech) or exposed to X-ray film. Protein abundance was quantified as the mean gray value for each membrane using ImageJ software (National Institutes of Health, Bethesda, MD) and was normalized to Ponceau S images. Additionally, negative control samples were included: primary only, secondary only, and IgG with secondary antibody to ensure antibody specificity.

\section{Measurement of Circulating Proteins}

Plasma LBP and SAA were determined using commercially available kits according to manufacturers' instructions (LBP, Hycult Biotech, Uden, the Netherlands; SAA, Tridelta Development Ltd., Kildare, Ireland; Suojala et al., 2008). The inter- and intra-assay coefficients of variation for LBP and SAA were 33.7 and $5.3 \%$, and 22.1 and $12.3 \%$, respectively. Serum and follicular fluid P4 were analyzed using a commercially available ELISA (EIA 156 DRG, Springfield, NJ; Silván et al., 1993). Serum and follicular fluid 17ß-estradiol (E2) were extracted and analyzed by RIA (Perry and Perry, 2008; limit of detection $0.33 \mathrm{pg} / \mathrm{mL}$ ). The intraassay coefficients of variation for P4 and E2 in serum were 4.0 and $6.1 \%$, respectively, and for follicular fluid were 4.0 and $4.0 \%$, respectively.

\section{Calculations and Statistical Analysis}

Western blot data were analyzed using a diagonal covariance structure with cow as the random effect and treatment as the fixed effect. Two-tailed $t$-tests were performed to analyze PCR data. All other parameters were analyzed using repeated measures with an autoregressive covariance structure and LPS infusion day as the repeated effect. Each specific variable's pre-infusion value (when available) served as a covariate. Effects of treatment, day, and treatment by day interaction were assessed using PROC MIXED (SAS Institute Inc., Cary, NC). To compare with baseline, the overall effects period and treatment (and their interaction) were also analyzed using PROC MIXED. Results are reported as least squares means and considered significant when $P$ $\leq 0.05$ and a tendency if $0.05<P \leq 0.10$.

\section{RESULTS}

Administrating LPS initially induced a febrile response in LPS-AL cows (d 1 to $3+0.49^{\circ} \mathrm{C}$ relative to baseline; $P<0.01$; Figure 1B), but no treatment differences were observed on d 4 to 6 . Relative to CON-PF, RR and HR of LPS-AL cows increased (16 and $11 \mathrm{bpm}$; respectively; $P<0.01$; Table 3 ) during $\mathrm{P} 2$. Relative to baseline, DMI of LPS-infused cows decreased $(28 \% ; P$ $<0.01)$ on $\mathrm{d} 1$ of infusion, after which it progressively increased with time $(P<0.01$; Figure $1 \mathrm{C})$ and returned to pre-infusion levels by d 6 of P2. The pattern and extent of reduced DMI was similar in CON-PF cows by experimental design. Milk yield from LPS-AL cows decreased $\sim 12 \%$ on d 1 of P2 $(P=0.01$; Figure 1D) relative to baseline; however, no overall treatment differences were observed during P2 $(P=0.65)$. Overall, LPS administration increased milk fat content $(19 \%$; $P=0.03$; particularly for $\mathrm{d} 1-3$, data not shown) and MUN (17\%; $P=0.04)$ compared with CON-PF cows (Table 3). Milk protein tended to be decreased $(4 \% ; P$ $=0.08$ ) with continuous LPS infusion (Table 3 ). Infusing LPS had no effect on other milk components $(P>$ 0.10 ; Table 3 ).

Lipopolysaccharide administration did not alter hepatic mRNA abundance of TLR4 or LBP (Figure 2 ). Also, no difference was observed in the mRNA abundance of genes analyzed at the end of P1. Hepatic transcript abundance of $A O A H$ tended to be elevated (5.8-fold) in LPS-AL cows compared with CON-PF ( $P$ $=0.10$; Figure 2). Additionally, hepatic RELA gene expression was numerically increased (2.7-fold) in LPSAL cows relative to CON-PF cows $(P=0.11$; Figure 2$)$. Progesterone metabolism enzymes CYP2C and CYP $3 A$ mRNA abundance were not affected by chronic LPS infusion (Figure 2; $P \geq 0.33$ ). No treatment differences in hepatic SOD1, VEGF, or SULT1E1 protein abundance were detected (Table 4; $P \geq 0.25$ ). Furthermore, liver, muscle, and adipose tissue AOAH protein abundance did not differ by treatment (Table $4 ; P \geq 0.41$ ). 
Table 3. Effects of chronic LPS infusion on production and physiological parameters

\begin{tabular}{|c|c|c|c|c|c|c|}
\hline \multirow[b]{2}{*}{ Parameter } & \multicolumn{2}{|c|}{ Treatment $^{1}$} & \multirow[b]{2}{*}{ SEM } & \multicolumn{3}{|c|}{$P$-value } \\
\hline & CON-PF & LPS-AL & & Treatment & Day & Treatment $\times$ day \\
\hline \multicolumn{7}{|l|}{ Milk component } \\
\hline Fat $(\%)$ & 3.40 & 4.04 & 0.18 & 0.03 & 0.11 & 0.29 \\
\hline Lactose $(\%)$ & 4.93 & 5.14 & 0.18 & 0.46 & 0.14 & 0.10 \\
\hline Protein $(\%)$ & 3.36 & 3.22 & 0.05 & 0.08 & 0.04 & 0.08 \\
\hline TS $(\%)$ & 12.18 & 12.77 & 0.21 & 0.07 & 0.03 & 0.32 \\
\hline MUN (mg/dL) & 11.13 & 12.97 & 0.53 & 0.04 & $<0.01$ & 0.08 \\
\hline SCC $($ cells $\times 1,000)$ & 182 & 207 & 17 & 0.32 & 0.56 & 0.84 \\
\hline \multicolumn{7}{|l|}{ Vital sign } \\
\hline $\mathrm{RR}^{2}(\mathrm{bpm})$ & 33 & 49 & 1 & $<0.01$ & $<0.01$ & $<0.01$ \\
\hline $\mathrm{HR}^{3}(\mathrm{bpm})$ & 77 & 88 & 2 & $<0.01$ & 0.32 & 0.12 \\
\hline
\end{tabular}

${ }^{1} \mathrm{CON}-\mathrm{PF}=$ saline infused, pair fed. LPS-AL $=$ LPS infused, ad libitum feed intake.

${ }^{2} \mathrm{RR}=$ respiration rate; $\mathrm{bpm}=$ breaths per minute.

${ }^{3} \mathrm{HH}=$ heart rate; $\mathrm{bpm}=$ beats per minute.

Overall during P2, LPS administration increased circulating LBP and SAA (40 and 118\%, respectively; $P$ $\leq 0.04$; Figures $3 \mathrm{~A}$ and $3 \mathrm{~B}$ ) relative to $\mathrm{CON}-\mathrm{PF}$ cows. Compared with $\mathrm{P} 1$, circulating LBP was increased in LPS-AL cows on d 1 of P2 $(102 \% ; P<0.01)$ and steadily declined with time. In contrast, SAA concentrations peaked on d 3 of $\mathrm{P} 2(213 \% ; P=0.01)$, relative to baseline. Circulating neutrophils were initially increased on $\mathrm{d} 1$ (45\%; $P=0.03$; Figure $3 \mathrm{C})$ and then

\section{$\square \mathrm{CON}-\mathrm{PF} \quad$ - LPS-AL}

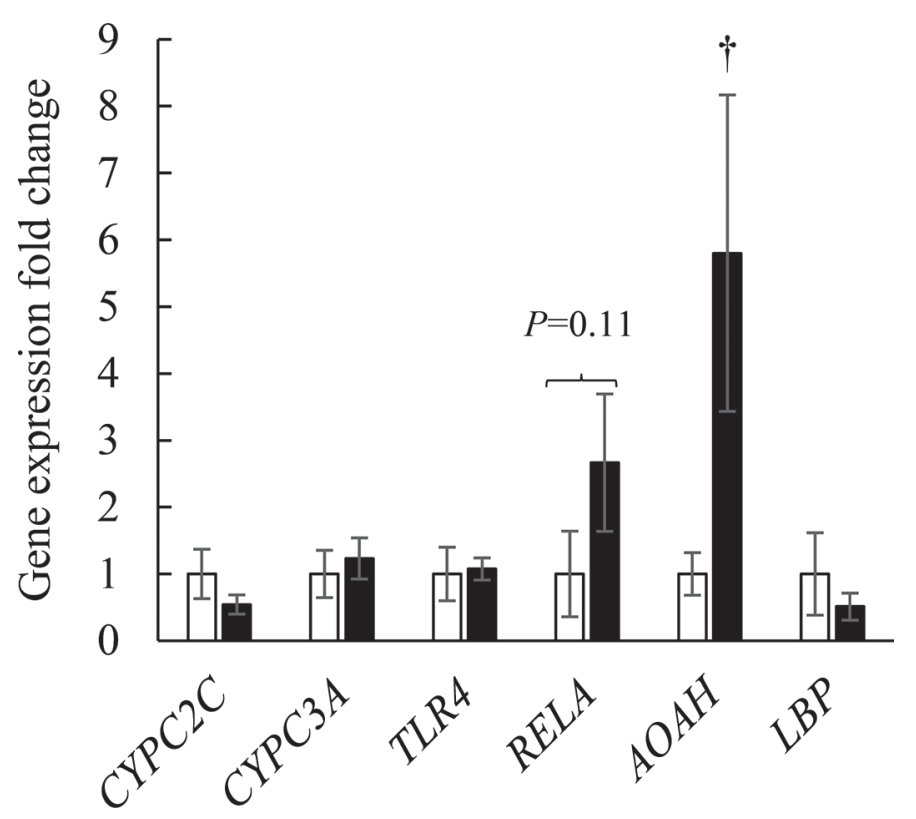

Figure 2. Effects of chronic LPS infusion on gene expression in whole liver lysate. Treatments include saline infused and pair fed (CON-PF) and LPS infused with ad libitum feed intake (LPS-AL). Values represent mean fold change \pm SEM. Genes that tended $(0.05<$ $P \leq 0.10)$ to be different between treatments are denoted by $\dagger$. tended to be decreased on d 3.5, 4, and $6(28,33$, and $35 \%$, respectively; $P=0.01$ ) in LPS-AL, relative to CON-PF cows. Similarly, lymphocytosis was present initially in LPS-AL relative to CON-PF cows with peak cell counts at $1.5 \mathrm{~d}$ (40\%; $P=0.09$; data not shown); however, lymphocytes did not differ between treatments for the remainder of the study. Conversely, circulating monocytes were decreased in LPS-AL cows for the first 2 d of P2 (40\%), then progressively increased from d 3 to $7(33 \%)$ relative to CON-PF $(P=0.02$; Figure $3 \mathrm{D})$.

The dominant follicle diameter increased by $\sim 30 \%$ in both CON-PF and LPS-AL ovaries between $\mathrm{d} 4$ and 7 postinduction of ovulation $(P=0.02)$, but no treatment effect was observed on follicle diameter $(P=$ 0.74 ; Figure $4 \mathrm{~A})$ or follicle volume $(P=0.93$; data not shown). Serum and follicular fluid $\mathrm{P} 4$ concentrations were not influenced by treatment $(P=0.76$ and $P=$ 0.72 , respectively; data not shown). Serum $17 \beta$-estradiol

Table 4. Effects of continuous LPS infusion on relative protein abundance

\begin{tabular}{lccc}
\hline & \multicolumn{2}{c}{ Treatment $^{2}$} & \\
\cline { 2 - 3 } $\begin{array}{l}\text { Tissue and } \\
\text { protein }\end{array}$ & CON-PF & LPS-AL & $P$-value \\
\hline Liver & & & \\
SULT1E1 & $1.00 \pm 0.10$ & $0.89 \pm 0.14$ & 0.54 \\
SOD1 & $1.00 \pm 0.11$ & $0.84 \pm 0.08$ & 0.25 \\
VEGF & $1.00 \pm 0.09$ & $0.86 \pm 0.20$ & 0.59 \\
AOAH & $1.00 \pm 0.29$ & $0.65 \pm 0.13$ & 0.41 \\
Adipose tissue & $1.00 \pm 0.12$ & $0.86 \pm 0.13$ & 0.46 \\
AOAH & $1.00 \pm 0.08$ & $0.99 \pm 0.12$ & 0.75 \\
Muscle & AOAH & & \\
\hline
\end{tabular}

${ }^{1}$ SULT1E1 = estrogen sulfotransferase; SOD1 = superoxide dismutase $1 ; \mathrm{VEGF}=$ vascular endothelial growth factor; AOAH = acyloxyacyl hydrolase.

${ }^{2} \mathrm{CON}-\mathrm{PF}=$ saline infused, pair fed; LPS-AL $=$ LPS infused, ad libitum feed intake. Data are reported as LSM \pm SEM. 


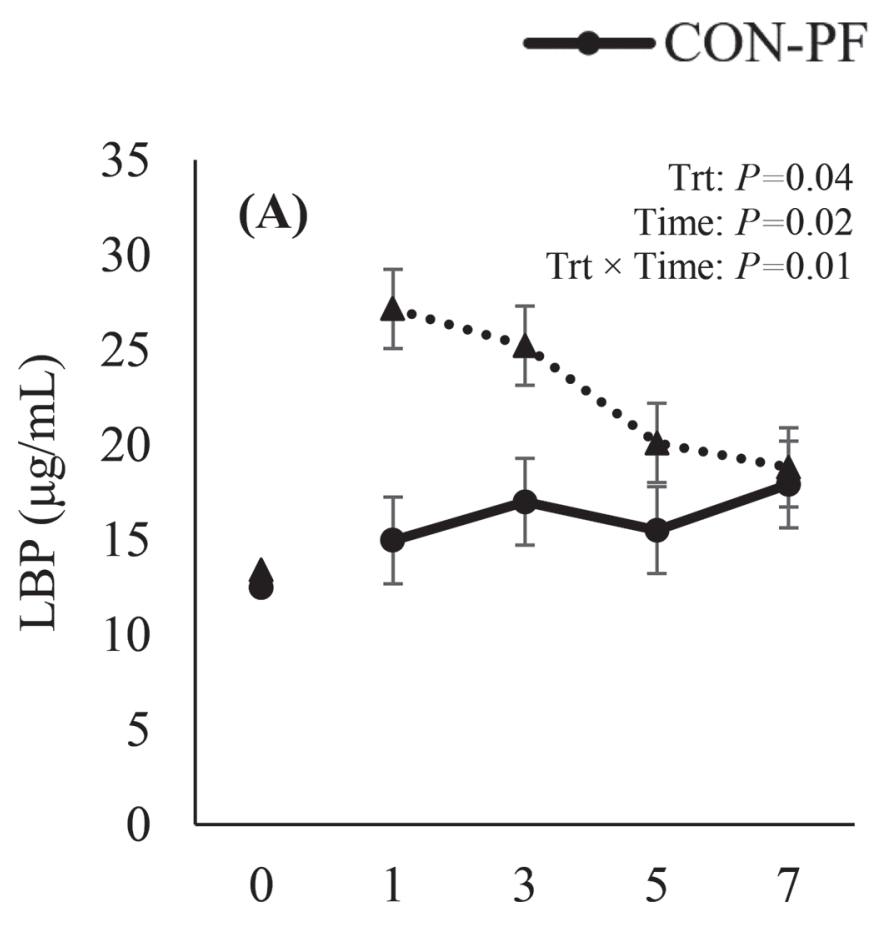

$\bullet \bullet \bullet \cdot$ LPS-AL
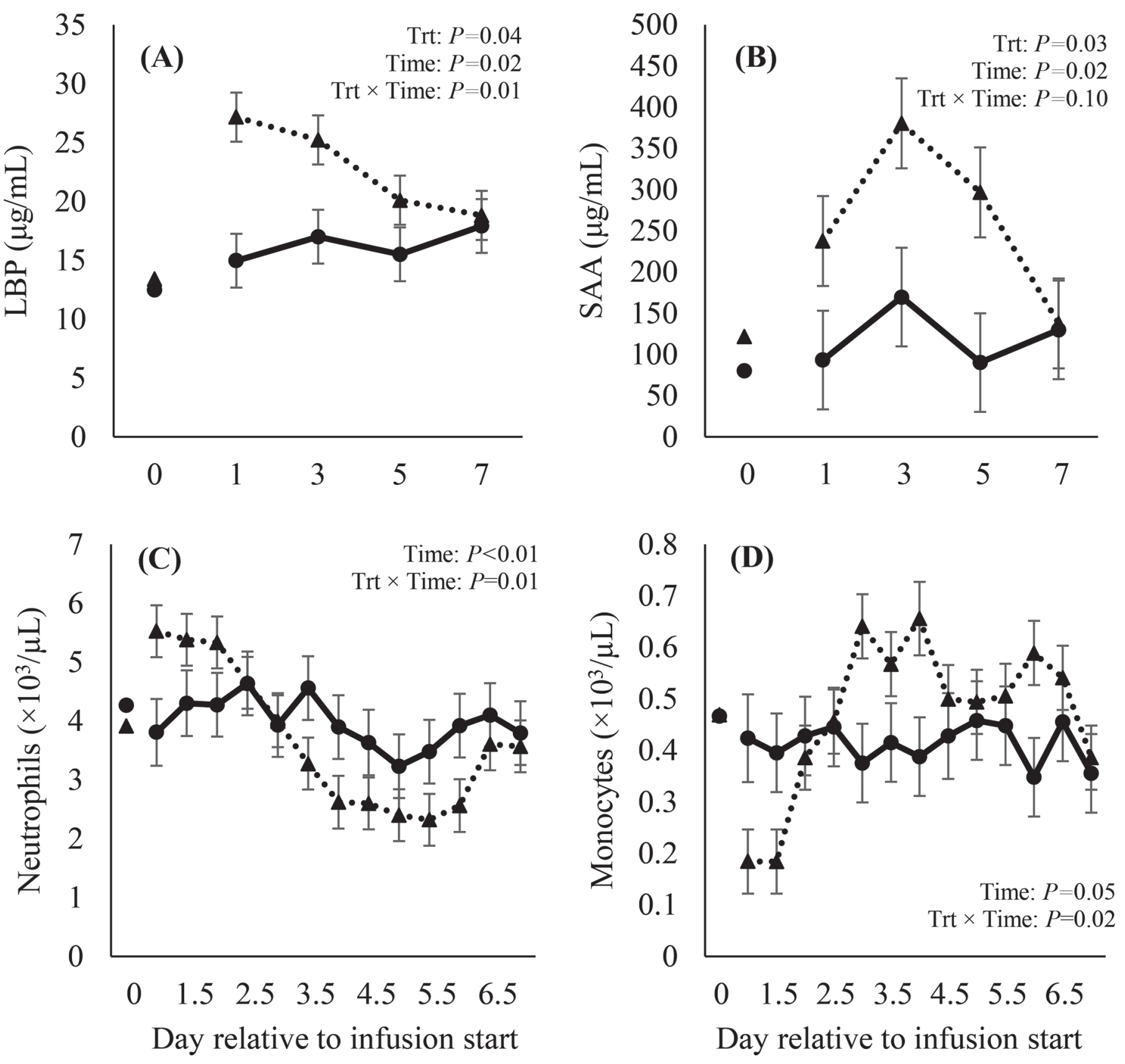

Figure 3. Effects of chronic LPS on circulating LPS-binding protein (LBP; A), serum amyloid A (SAA; B), neutrophils (C), and monocytes (D). Treatments include saline infused and pair fed (CON-PF) and LPS infused with ad libitum feed intake (LPS-AL). Results are expressed as $\mathrm{LSM} \pm \mathrm{SEM}$. Embedded $P$-values represent differences between CON-PF and LPS-AL during period 2.

content tended to increase after $7 \mathrm{~d}$ of LPS exposure (1.14 vs. $0.53 \mathrm{pg} / \mathrm{mL} ; P=0.08$ : Figure $4 \mathrm{~B})$ in LPS-AL cows compared with CON-PF. No treatment difference was observed in follicular fluid E2 concentrations $(P=$ 0.84; Figure 4C).

\section{DISCUSSION}

An activated immune system requires a large amount of energy as demonstrated in swine and cows (Johnson, 2012; Kvidera et al., 2017, respectively), which 


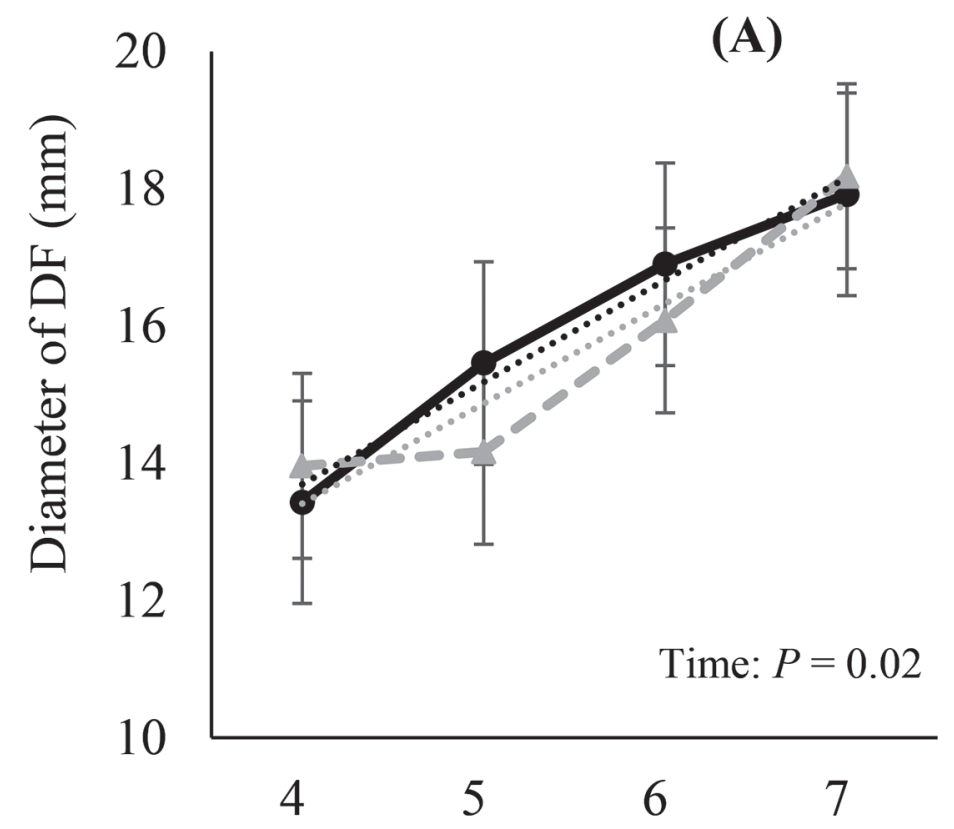

Day relative to infusion start
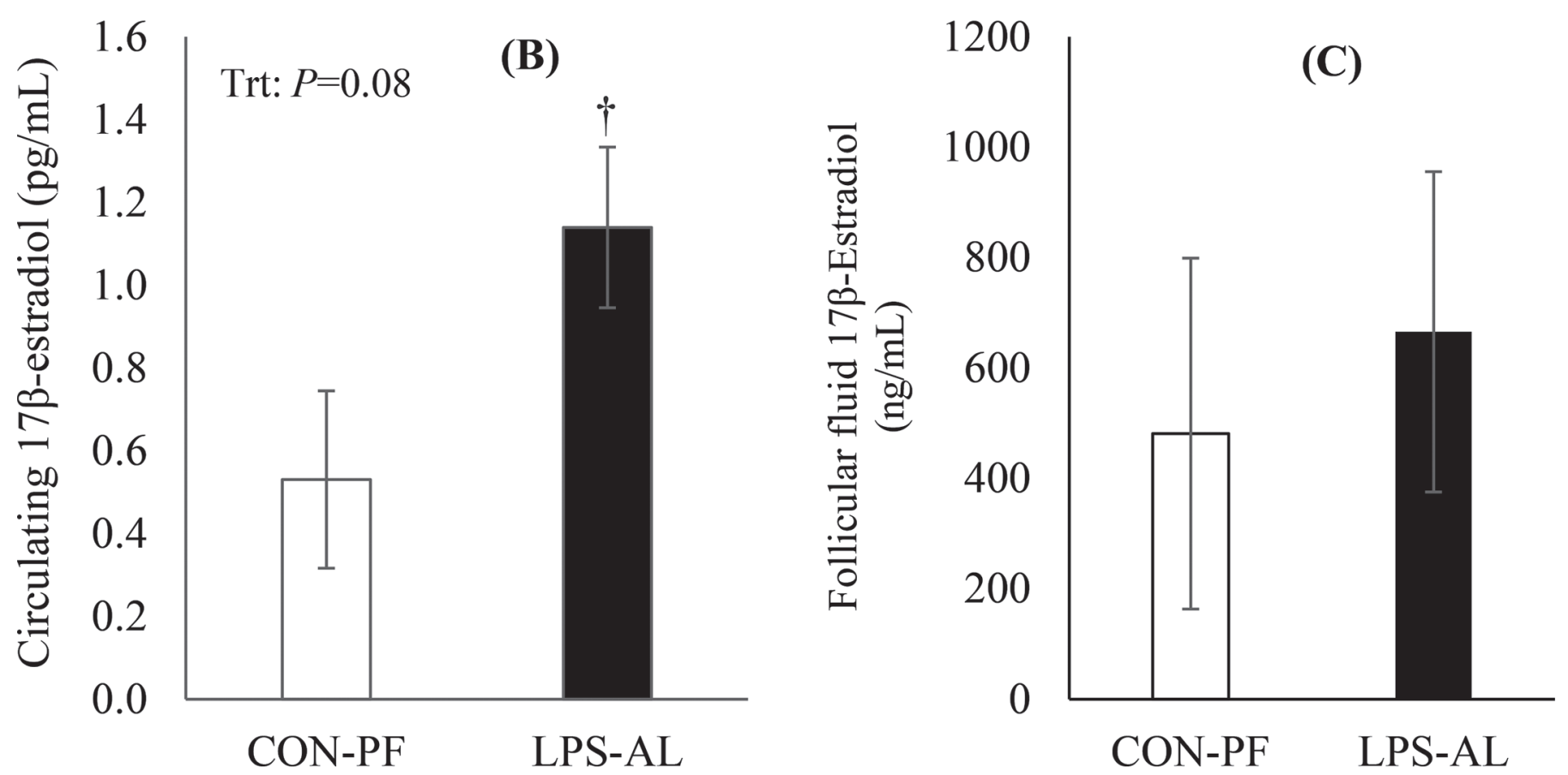

Figure 4. Effects of chronic LPS on dominant follicle (DF) size and rate of growth (A), d-7 serum 17ß-estradiol (E2; B), and d-7 follicular fluid E2 (C). Treatments include saline infused and pair fed (CON-PF) and LPS infused with ad libitum feed intake (LPS-AL). Cows were synchronized and the first wave of follicular growth was monitored. Results are expressed as LSM \pm SEM. A tendency $(0.05<P \leq 0.10)$ toward a difference in circulating $\mathrm{E} 2$ is indicated by $\dagger$. 
is reallocated from profitable purposes, resulting in decreased milk synthesis and growth, inefficient feed utilization, and poor reproduction (Lochmiller and Deerenberg, 2000). Immunoactivation is most often experimentally modeled using a single, high-dose LPS bolus; however, this likely does not represent typical endotoxin exposures, which are expected to be more chronic and continuous in nature and reflective of bacterial overgrowth, proliferation, and death/lysis (both of which result in LPS release; Crutchley et al., 1967; Goris et al., 1988). Short-term but continuous LPS infusion prompts a less aggressive and more sustained release of inflammatory mediators, probably a more appropriate model of chronic inflammation than a bolus in humans (Taudorf et al., 2007). Hence, key knowledge gaps remain in distinguishing how accurate single or repeated LPS boluses mimic chronic, naturally occurring pathogen exposure, particularly in production farm animals. Thus, experimental objectives were to develop a method of continuous and increasing LPS infusion in lactating cows conducive to a more biologically relevant exposure.

Reaction to PAMP such as LPS can vary in magnitude as repeated or continuous exposure to a constant amount of endotoxin causes hyporesponsiveness in multiple in vivo and in vitro models (i.e., tolerance; Beeson, 1947; West and Heagy, 2002). Consequently, the increasing LPS dose regimen in the current study was developed both to emulate bacterial growth and to prevent LPS tolerance development. Contrary to our expectations, LPS tolerance clearly developed as indicated by Tr, DMI, and milk yield, which all returned to normal or CON-PF levels by d 6 of infusion. These data indicate a remarkable ability for lactating cows to adapt to increasing endotoxin exposure as a relatively low starting dose was used $(0.4 \mu \mathrm{g} / \mathrm{kg}$ of BW over 24 $\mathrm{h}$ on $\mathrm{d} 1$ ) and sequentially increased to an extremely high quantity, if given as a bolus $(3.56 \mu \mathrm{g} / \mathrm{kg}$ of $\mathrm{BW}$ over $24 \mathrm{~h}$ on d 7). In fact, a bolus dose of just $2.0 \mu \mathrm{g} / \mathrm{kg}$ of BW can be fatal in LPS-naive lactating cows (Waldron et al., 2003); thus, an initial conservative LPS dosing regimen was used herein. Because of the obvious hyporesponsiveness, a logistical curve of dose increase (more natural to bacterial replication) and more aggressive starting dose may be warranted to better mimic infection and avoid LPS tolerance development. Additionally, including other PAMP (e.g., lipoteichoic acid, dsRNA) would be interesting as natural infections certainly include a larger variety of PAMP than a specific LPS. Further, comparing and contrasting LPS administration models (i.v., i.m., intraperitoneal, in vitro, and so on) to natural disease states (mastitis, metritis, pneumonia, and so on) requires caution because there are numerous pathophysiological differences (Seemann et al., 2017).

In agreement with previous reports (Waldron et al., 2006; Moyes et al., 2014; Horst et al., 2018), LPS infusion initially decreased DMI and the pattern was similar in CON-PF cows by experimental design. In contrast to expectations, milk yield did not differ between treatments but remained depressed during the infusion period, and this is mostly explained by decreased DMI, which did not return to baseline until d 6 . In our LPS bolus experiments, the pair-fed controls produce substantially more milk than immunoactivated cows (Kvidera et al., 2017; Horst et al., 2018). In LPS-AL cows, overall milk fat content and MUN was increased. Our milk fat content data agree with others (Shuster et al., 1991) and may represent a dilution effect as the temporal pattern was similar to milk yield (i.e., largest effect observed during the first $3 \mathrm{~d}$ of P2) and clearly contradicts the hypothesis that LPS is involved with milk fat depression (Zebeli and Ametaj, 2009). Increased circulating MUN in LPS-AL cows is in alignment with the circulating BUN data (see companion paper; Horst et al., 2019). We speculate these makers of protein metabolism indicate endotoxemia-induced increased skeletal muscle catabolism, commonly reported in monogastrics (Bruins et al., 2003; Iseri and Klasing, 2013). However, interpreting circulating urea dynamics in ruminants is complicated due to the contribution of rumen-derived ammonia and the confounding effect systemic LPS has on changes to the rumen microbiome (Jing et al., 2014). Surprisingly, milk yield appeared to be the first parameter to develop LPS tolerance as it was similar to CON-PF cows throughout P2. This occurred despite increased Tr, acute phase proteins, and altered leukocyte dynamics in LPS-infused cows and in contrast to our previous reports using a 1.5 and 0.375 $\mu \mathrm{g} / \mathrm{kg}$ LPS bolus, which resulted in an 80 and $74 \%$ decrease in milk yield (Kvidera et al., 2017; Horst et al., 2018, respectively), amounts of LPS less than $50 \%$ of the collective dose we administered on $\mathrm{d} 7$.

In agreement with bolus studies (Carroll et al., 2009; Graugnard et al., 2013; Kvidera et al., 2017), LPS administration caused an acute phase protein (LBP and SAA) response further indicating successful immunoactivation. Upon immunoactivation, the liver increases production of positive acute phase proteins such as haptoglobin, SAA, and LBP, which aid in immune system responses and endotoxin detoxification (Ceciliani et al., 2012). The increase in acute phase proteins is consistent with other ruminant literature; however, substantial variation is present in baseline values and magnitudes of change, particularly for LBP (Schroedl et al., 2001; Carroll et al., 2009; Plessers et al., 2015; 
Kvidera et al., 2017). This is likely due to differences in models, route of LPS administration, laboratory procedures, or a combination of these, but the directional change remains consistent. The liver's role in immunity and endotoxin detoxification in humans is important (Strnad et al., 2017) because, within minutes, a large proportion of i.v. injected bacteria are localized within human hepatic tissue (Yan et al., 2014).

Together with the APP, local immune cells serve as the first line of defense in the cellular response. Leukocyte recognition of antigens (e.g., LPS) by its pattern recognition receptor (i.e., TLR4) initiates a signaling cascade culminating in the phosphorylation of RELassociated protein (a subunit of transcription factor NFkB; pRELA) and production of inflammatory cytokines (Akira et al., 2006; Lu et al., 2008). Mechanisms mediating LPS tolerance are complex, but are thought to primarily include both reduced leukocyte TLR4 receptor abundance and capacity to produce cytokines (West and Heagy, 2002). Interestingly, and in agreement with previous work in mice and in bovine mammary epithelial cells (Matsumura et al., 2000; Strandberg et al., 2005), LPS administration did not alter TLR 4 mRNA abundance, but tended to increase hepatic RELA gene expression, demonstrating ostensible hepatic TLR4 pathway activation. Gene expression of liver $A O A H$ (which detoxifies LPS) tended to increase, but AOAH protein abundance was similar in LPS-infused cows. Lipopolysaccharide binding protein (increased until d 7 of infusion) can rearrange LPS to better expose the lipid A portion of LPS for detoxification by AOAH (Gioannini et al., 2007). Unfortunately, analyzing gene expression and protein abundance from a single time point does not reflect the temporal pattern of these detoxification proteins, nor does it demonstrate activity. Regardless, the positive effect of LPS on mRNA encoding $A O A H$ supports that LPS detoxification via $\mathrm{AOAH}$ was likely occurring. Reactive oxygen species production can be stimulated by LPS (Rietschel et al., 1994), and the antioxidant protein SOD1 diminishes $\mathrm{NF} \kappa \mathrm{B}$ activation and cytokine release in microglial cells in vitro (Dimayuga et al., 2007). Compared with CON$\mathrm{PF}$ cows, we observed no treatment difference in liver SOD1 protein abundance during P2, which contrasts with a previous report demonstrating an acute LPS bolus decreased murine hepatic SOD1 gene expression (Fang et al., 2004). Both LPS and ROS can promote VEGF production (Chua et al., 1998; Matsushita et al., 1999), and VEGF is important for angiogenesis and is involved in pathological conditions such as chronic inflammation (Ferrara and Henzel, 1989; Jackson et al., 1997); however, we observed no difference in hepatic VEGF protein abundance at the end of LPS chronic in- fusion. It would be of interest to characterize temporal patterns in mRNA and protein abundance of the targets investigated, as they could potentially be dynamic throughout long-term LPS exposure.

Local leukocyte stimulation and release of inflammatory mediators stimulate further immune cell proliferation and recruitment to the infection site (Lang et al., 1992). In bolus LPS studies, a biphasic response is typically observed with initial leukopenia and subsequent leukocytosis (Kvidera et al., 2017; Horst et al., 2018). Herein circulating monocytes exhibited a similar pattern, whereas neutrophil and lymphocyte count dynamics were opposite. Reasons for this discrepancy are unclear; however, it may be explained by differing recruitment patterns in acute versus chronic inflammation or timing of sample collection. Neutrophils are typically the first line of defense in the cellular response (Kanthack and Hardy, 1894; Nathan, 2006) and are the dominant cell type in innate immunity; therefore, proliferation rate may have been increased in the acute response. In contrast, monocyte proliferation would likely occur later and in response to activated neutrophils (Nathan, 2006). A clear limitation in measuring circulating leukocyte patterns is the inability to distinguish between increased proliferation, leukocyte infiltration, or impaired extravasation equipment (i.e., adhesion molecules). Regardless, further investigation into differing temporal patterns and whether leukocyte infiltration affects metabolic and functional activities of different tissues are warranted.

Cows with metritis, associated with LPS-producing bacterial strains, have delayed follicular growth and are less likely to ovulate (Sheldon et al., 2009). After 7 $\mathrm{d}$ of LPS infusion during the first wave of follicular growth, we observed no differences in dominant follicle size or growth rate of the dominant follicle in LPS-AL compared with CON-PF cows. This agrees with an ex vivo study in which no difference in follicle size was observed after culture of the bovine ovarian cortex for $6 \mathrm{~d}$ with LPS (Bromfield and Sheldon, 2013). Additionally, intrauterine LPS infusion in cows did not affect dominant follicle size or growth rate (Williams et al., 2008). Thus, both in vitro and in vivo data suggest that gross dominant follicle growth is not altered by LPS. However, limitations to our experiment (such as lack of ovary collection) did not permit analyzing the effect of chronic LPS infusion at the molecular level, nor could we assess the influence of endotoxemia on ovarian steroidogenic enzyme abundance and activity, oocyte growth or viability, and primordial follicle pool activation. Bromfield and Sheldon (2013) demonstrated that LPS accelerated premature primordial follicular activation, thereby contributing to primordial 
follicle pool depletion. They also demonstrated that LPS induced cumulus oocyte complex expansion and increased the rate of meiotic arrest and germinal vesicle breakdown failure (Bromfield and Sheldon, 2013). Similar effects could have been occurring in our study but were beyond the scope of our investigation. Studying the long-term in vivo effects of chronic LPS on ovarian physiology remains warranted and is of obvious commercial relevance.

The major ovarian steroid hormones are E2 and P4. Endotoxins can infiltrate follicular fluid and alter steroidogenesis (Herath et al., 2007; Williams et al., 2008; Magata et al., 2014). After 7 d of LPS infusion, we detected no difference in follicular fluid E2 or P4 concentrations between LPS-AL and CON-PF cows. Additionally, and in contrast to studies demonstrating decreased circulating P4 in LPS-infused goats and cows (Fredriksson et al., 1985; Giri et al., 1990), we observed no difference in serum P4 concentrations. Interestingly, our results agree with Tuo et al. (1999) who also observed no difference in circulating $\mathrm{P} 4$ after intrauterine LPS infusions in pigs. In the current experiment, a tendency was observed for increased serum E2 in LPS-AL cows relative to CON-PF cows on $\mathrm{d} 7$. Previous reports also indicate increased plasma E2 after uterine bacterial contamination (Sheldon et al., 2002); however, the majority of the literature indicate that LPS (bolus designs) decreases E2 production (Peter et al., 1990; Suzuki et al., 2001; Shimizu et al., 2012). Interestingly, Kahl et al. (2011) report that pre-treating steers with exogenous E2 enhanced the pro-inflammatory response to an LPS bolus, suggesting that E2 augments inflammation. Cows injected i.v. with LPS at the onset of estrus have longer estrus to ovulation windows or inhibition of ovulation entirely, and increased E2 was reported before delayed ovulation (Lavon et al., 2008). Chai et al. (2015) demonstrated that LPS induces hepatic expression of SULT1E1, a deactivator of estrogens (Song, 2001), and that SULT1E1 is a transcriptional target of NFKB. However, we did not observe an effect of chronic LPS on hepatic SULT1E1 protein abundance. Consequently, the effects of endotoxemia on ovarian and systemic steroid metabolism remain to be clearly elucidated, but its potential effect on practical on-farm reproduction variables is clear. The effects of imposing a progressively increasing dose of LPS to coincide with the proestrus and estrus stages of the estrous cycle on preovulatory follicle development, luteinizing hormone pulsatility, circulating E2 concentrations, and interval to ovulation warrant further investigation.

Despite the fact that LPS is a catabolic signal, LPS-AL cows were hyperinsulinemic $(\sim 140 \%)$ relative to CON-PF cows (see companion paper; Horst et al.,
2019), and this agrees with multiple reports (Waldron et al., 2003; Baumgard and Rhoads, 2013; Kvidera et al., 2017). Interestingly, hepatic gene expression of $\mathrm{P} 4$ metabolism enzymes (CYP2C and CYP3A) are decreased by hyperinsulinemia (Lemley et al., 2008). In mice, LPS also decreased $C Y P 2 C$ and $C Y P 3 A$ mRNA as well as CYP3A protein abundance (Moriya et al., 2014). However, in the current model of chronic, progressively increasing LPS exposure, LPS did not affect CYP2C or CYP3A gene expression after $7 \mathrm{~d}$ of infusion. Collectively, the little to no changes in the hepatic molecular data and circulating E2 and P4 are additional metrics illustrating the extent to which dairy cows can become tolerant to continuous and increasing LPS exposure.

Many of the immunoactivation events studied herein have relevance to the periparturient period and heatstressed cows. However, we studied the disrupting effects of LPS in mid-lactation healthy cows in thermal neutral conditions for the following reasons: (1) the transitioning cow is experiencing a variety of physiological events that are largely independent (seemingly) of the immunologic events described above and (2) the variation in nutrient partitioning variables (metabolic and endocrine) during both the transition period and heat stress is extensive, which creates pragmatic issues in our intensive experimental design. Consequently, using mid-lactation healthy cows whose phenotype (production, metabolism, immunology, and so on) was in a relative steady state allowed for the isolation of LPS effects by minimizing other potential unknowns associated with the physiological acclimation to both lactation and hyperthermia.

\section{CONCLUSIONS}

From a production standpoint, immunoactivation negatively affects animal productivity, reproduction, and welfare. Although the effects of LPS bolus-induced immunoactivation are well studied, this current experimental design provides an alternative model for evaluating chronic inflammation and is likely more physiologically relevant for studying biologically applicable infections. Although some signs of immunoactivation were present, it is clear that cows become tolerant to continuous and rapidly increasing levels of LPS. Thus, future experiments will need to be more aggressive with the LPS infusion paradigm or use multiple virulence factors. Regardless, the lack of observable effects on reproductive phenotypes was surprising and further suggests that the current design needs modifying to more accurately model how chronic infection and inflammation negatively affect ovarian function. 


\section{ACKNOWLEDGMENTS}

Results described herein were supported in part by the Agricultural and Food Research Initiative Competitive Grant no. 2017-05931 from the USDA National Institute of Food and Agriculture (Washington, DC) and the Norman Jacobson Endowed Professorship at Iowa State University.

\section{REFERENCES}

Akira, S., S. Uematsu, and O. Takeuchi. 2006. Pathogen recognition and innate immunity. Cell 124:783-801. https://doi.org/10.1016/ j.cell.2006.02.015.

AOAC International. 1995. AOAC official method 972.16. Fat, lactose, protein, and solids in milk. Mid infrared spectroscopic method. Pages 23-26 in Official Methods of Analysis. 16th ed. Vol. 2. AOAC International, Arlington, VA.

Ballou, M. A. 2012. Growth and Development Symposium: Inflammation: Role in the etiology and pathophysiology of clinical mastitis in dairy cows. J. Anim. Sci. 90:1466-1478. https://doi.org/10 $.2527 /$ jas.2011-4663.

Baumgard, L. H., and R. P. Rhoads. 2013. Effects of heat stress on postabsorptive metabolism and energetics. Annu. Rev. Anim. Biosci. 1:311-337. https://doi.org/10.1146/annurev-animal $-031412-103644$.

Beeson, P. B. 1947. Tolerance to bacterial pyrogens. I. Factors influencing its development. J. Exp. Med. 86:29-38.

Bidne, K. L., M. J. Dickson, J. W. Ross, L. H. Baumgard, and A. F. Keating. 2018a. Disruption of female reproductive function by endotoxins. Reproduction 155:R169-R181. https://doi.org/10.1530/ REP-17-0406.

Bidne, K. L., S. K. Kvidera, J. W. Ross, L. H. Baumgard, and A. F. Keating. 2018b. Impact of repeated lipopolysaccharide administration on ovarian signaling during the follicular phase of the estrous cycle in post-pubertal pigs. J. Anim. Sci. 96:3622-3634. https:// doi.org/10.1093/jas/sky226.

Bromfield, J. J., and I. M. Sheldon. 2013. Lipopolysaccharide reduces the primordial follicle pool in the bovine ovarian cortex ex vivo and in the murine ovary in vivo. Biol. Reprod. 88:98. https://doi .org/10.1095/biolreprod.112.106914.

Bruins, M. J., N. E. P. Deutz, and P. B. Soeters. 2003. Aspects of organ protein, amino acid and glucose metabolism in a porcine model of hypermetabolic sepsis. Clin. Sci. (Lond.) 104:127-141. https://doi.org/10.1042/CS20020275.

Carroll, J. A., R. R. Reuter, C. C. Chase Jr., S. W. Coleman, D. G. Riley, D. E. Spiers, J. D. Arthington, and M. L. Galyean. 2009. Profile of the bovine acute-phase response following an intravenous bolus-dose lipopolysaccharide challenge. Innate Immun. 15:81-89. https://doi.org/10.1177/1753425908099170.

Ceciliani, F., J. J. Ceron, P. D. Eckersall, and H. Sauerwein. 2012. Acute phase proteins in ruminants. J. Proteomics 75:4207-4231. https://doi.org/10.1016/j.jprot.2012.04.004.

Chai, X., Y. Guo, M. Jiang, B. Hu, Z. Li, J. Fan, M. Deng, T. R. Billiar, H. R. Kucera, N. W. Gaikwad, M. Xu, P. Lu, J. Yan, H. Fu, Y. Liu, L. Yu, M. Huang, S. Zeng, and W. Xie. 2015. Oestrogen sulfotransferase ablation sensitizes mice to sepsis. Nat. Commun. 6:7979. https://doi.org/10.1038/ncomms8979.

Chow, J. C., D. W. Young, D. T. Golenbock, W. J. Christ, and F. Gusovsky. 1999. Toll-like receptor-4 mediates lipopolysaccharideinduced signal transduction. J. Biol. Chem. 274:10689-10692. https://doi.org/10.1074/jbc.274.16.10689.

Chua, C. C., R. C. Hamdy, and B. H. Chua. 1998. Upregulation of vascular endothelial growth factor by $\mathrm{H} 2 \mathrm{O} 2$ in rat heart endothelial cells. Free Radic. Biol. Med. 25:891-897. https://doi.org/10.1016/ S0891-5849(98)00115-4.

Crutchley, M. J., D. G. Marsh, and J. Cameron. 1967. Free endotoxin. Nature 214:1052.
Dimayuga, F. O., C. Wang, J. M. Clark, E. R. Dimayuga, V. M. Dimayuga, and A. J. Bruce-Keller. 2007. SOD1 overexpression alters ROS production and reduces neurotoxic inflammatory signaling in microglial cells. J. Neuroimmunol. 182:89-99. https://doi.org/10 .1016/j.jneuroim.2006.10.003.

Dohmen, M. J. W., K. Joop, A. Sturk, P. E. J. Bols, and J. A. C. M. Lohuis. 2000. Relationship between intra-uterine bacterial contamination, endotoxin levels and the development of endometritis in postpartum cows with dystocia or retained placenta. Theriogenology 54:1019-1032. https://doi.org/10.1016/S0093-691X(00)00410 $-6$.

Espey, L. L. 1980. Ovulation as an inflammatory reaction-A hypothesis. Biol. Reprod. 22:73-106. https://doi.org/10.1095/biolreprod22 .1.73.

Fang, C., S. Yoon, N. Tindberg, H. A. Jarvelainen, K. O. Lindros, and M. Ingelman-Sundberg. 2004. Hepatic expression of multiple acute phase proteins and down-regulation of nuclear receptors after acute endotoxin exposure. Biochem. Pharmacol. 67:1389-1397. https://doi.org/10.1016/j.bcp.2003.12.012.

Ferrara, N., and W. J. Henzel. 1989. Pituitary follicular cells secrete a novel heparin-binding growth factor specific for vascular endothelial cells. Biochem. Biophys. Res. Commun. 161:851-858. https:// doi.org/10.1016/0006-291X(89)92678-8.

Fonseca, F. A., J. H. Britt, B. T. McDaniel, J. C. Wilk, A. H. Rakes, N. J. Moeller, and H. Karg. 1983. Reproductive traits of Holsteins and Jerseys. Effects of age, milk yield, and clinical abnormalities on involution of cervix and uterus, ovulation, estrous cycles, detection of estrus, conception rate, and days open. J. Dairy Sci. 66:1128-1147. https://doi.org/10.3168/jds.S0022-0302(83)81910 $-9$.

Fredriksson, G., H. Kindahl, and L. E. Edqvist. 1985. Endotoxin-induced prostaglandin release and corpus luteum function in goats. Anim. Reprod. Sci. 8:109-121. https://doi.org/10.1016/0378 $-4320(85) 90077-6$.

Gilbert, R. O., W. T. K. Bosu, and A. T. Peter. 1990. The effect of Escherichia coli endotoxin on luteal function in Holstein heifers. Theriogenology 33:645-651. https://doi.org/10.1016/0093 -691X(90)90541-Z.

Gioannini, T. L., A. Teghanemt, D. Zhang, P. Prohinar, E. N. Levis, R. S. Munford, and J. P. Weiss. 2007. Endotoxin-binding proteins modulate the susceptibility of bacterial endotoxin to deacylation by acyloxyacyl hydrolase. J. Biol. Chem. 282:7877-7884. https:// doi.org/10.1074/jbc.M605031200.

Giri, S. N., P. Emau, J. S. Cullor, G. H. Stabenfeldt, M. L. Bruss, R. H. Bondurant, and B. I. Osburn. 1990. Effects of endotoxin infusion on circulating levels of eicosanoids, progesterone, cortisol, glucose and lactic acid, and abortion in pregnant cows. Vet. Microbiol. 21:211-231. https://doi.org/10.1016/0378-1135(90)90033-R.

Goris, H., F. de Boer, and D. van der Waaij. 1988. Kinetics of endotoxin release by gram-negative bacteria in the intestinal tract of mice during oral administration of bacitracin and during in vitro growth. Scand. J. Infect. Dis. 20:213-219. https://doi.org/10 $.3109 / 00365548809032440$

Gozho, G. N., J. C. Plaizier, D. O. Krause, A. D. Kennedy, and K. M. Wittenberg. 2005. Subacute ruminal acidosis induces ruminal lipopolysaccharide endotoxin release and triggers an inflammatory response. J. Dairy Sci. 88:1399-1403. https://doi.org/10.3168/jds .S0022-0302(05)72807-1.

Graugnard, D. E., K. Moyes, E. Trevisi, M. Khan, D. Keisler, J. Drackley, G. Bertoni, and J. Loor. 2013. Liver lipid content and inflammometabolic indices in peripartal dairy cows are altered in response to prepartal energy intake and postpartal intramammary inflammatory challenge. J. Dairy Sci. 96:918-935. https://doi.org/ $10.3168 /$ jds.2012-5676.

Herath, S., E. J. Williams, S. T. Lilly, R. O. Gilbert, H. Dobson, C E. Bryant, and I. M. Sheldon. 2007. Ovarian follicular cells have innate immune capabilities that modulate their endocrine function. Reproduction 134:683-693. https://doi.org/10.1530/REP-07 -0229 .

Horst, E. A., S. K. Kvidera, M. J. Dickson, C. S. McCarthy, E. J. Mayorga, M. Al-Qaisi, H. A. Ramirez, A. F. Keating, and L. H. 
Baumgard. 2019. Effects of continuous and increasing lipopolysaccharide infusion on basal and stimulated metabolism in lactating Holstein cows. J. Dairy Sci. 102:3584-3597. https://doi.org/10 .3168/jds.2018-15627.

Horst, E. A., S. K. Kvidera, E. J. Mayorga, C. S. Shouse, M. Al-Qaisi, M. J. Dickson, J. Ydstie, H. A. Ramirez Ramirez, A. F. Keating, D. J. Dickson, K. E. Griswold, and L. H. Baumgard. 2018. Effect of chromium on bioenergetics and leukocyte dynamics following immunoactivation in lactating Holstein cows. J. Dairy Sci. 101:5515-5530. https://doi.org/10.3168/jds.2017-13899.

Hudson, C. D., A. J. Bradley, J. E. Breen, and M. J. Green. 2012. Associations between udder health and reproductive performance in United Kingdom dairy cows. J. Dairy Sci. 95:3683-3697. https:// doi.org/10.3168/jds.2011-4629.

Huntley, N. F., C. Martin Nyachoti, and J. F. Patience. 2018. Lipopolysaccharide immune stimulation but not $\beta$-mannanase supplementation affects maintenance energy requirements in young weaned pigs. J. Anim. Sci. Biotechnol. 9:47. https://doi.org/10 .1186/s40104-018-0264-y.

Iseri, V. J., and K. C. Klasing. 2013. Dynamics of the systemic components of the chicken (Gallus gallus domesticus) immune system following activation by Escherichia coli; implications for the costs of immunity. Dev. Comp. Immunol. 40:248-257. https://doi.org/ 10.1016/j.dci.2013.02.005.

Jackson, J. R., M. P. Seed, C. H. Kircher, D. A. Willoughby, and J. D. Winkler. 1997. The codependence of angiogenesis and chronic inflammation. FASEB J. 11:457-465.

Jing, L., R. Zhang, Y. Liu, W. Zhu, and S. Mao. 2014. Intravenous lipopolysaccharide challenge alters ruminal bacterial microbiota and disrupts ruminal metabolism in dairy cattle. Br. J. Nutr. 112:170 182. https://doi.org/10.1017/S000711451400066X.

Johnson, R. W. 2012. Fueling the immune response: What's the cost? Pages 211-223 in Feed Efficiency in Swine. John Patience, ed. Wageningen Academic Publishers, Wageningen, the Netherlands.

Kahl, S., T. H. Elsasser, and C. J. Li. 2011. Modeling the effects of estradiol and progesterone on the acute phase proinflammatory axis: Variability in tumor necrosis factor- $\alpha$, nitric oxide, and xanthine oxidase responses to endotoxin challenge in steers. Domest. Anim. Endocrinol. 40:213-221. https://doi.org/10.1016/j.domaniend 2011.01.003.

Kanthack, A. A., and W. B. Hardy. 1894. The morphology and distribution of the wandering cells of mammalia. J. Physiol. 17:81-119. https://doi.org/10.1113/jphysiol.1894.sp000520.

Kujjo, L. L., W. T. Bosu, and G. I. Perez. 1995. Opioid peptides involvement in endotoxin-induced suppression of LH secretion in ovariectomized Holstein heifers. Reprod. Toxicol. 9:169-174. https: //doi.org/10.1016/0890-6238(94)00068-9.

Kvidera, S. K., E. A. Horst, M. Abuajamieh, E. Mayorga, M. Sanz Fernandez, and L. H. Baumgard. 2017. Glucose requirements of an activated immune system in lactating Holstein cows. J. Dairy Sci. 100:2360-2374. https://doi.org/10.3168/jds.2016-12001.

Lang, C. H., G. J. Bagby, C. Dobrescu, A. Ottlakan, and J. J. Spitzer. 1992. Sepsis- and endotoxin-induced increase in organ glucose uptake in leukocyte-depleted rats. Am. J. Physiol. 263:R1324-R1332. https://doi.org/10.1152/ajpregu.1992.263.6.R1324.

Lavon, Y., G. Leitner, T. Goshen, R. Braw-Tal, S. Jacoby, and D. Wolfenson. 2008. Exposure to endotoxin during estrus alters the timing of ovulation and hormonal concentrations in cows. Theriogenology 70:956-967. https://doi.org/10.1016/j.theriogenology .2008.05.058.

Lemley, C. O., S. T. Butler, W. R. Butler, and M. E. Wilson. 2008. Short Communication: Insulin alters hepatic progesterone catabolic enzymes cytochrome P450 2C and 3A in dairy cows. J. Dairy Sci. 91:641-645. https://doi.org/10.3168/jds.2007-0636.

Leury, B. J., L. H. Baumgard, S. S. Block, N. Segoale, R. A. Ehrhardt, R. P. Rhoads, D. E. Bauman, A. W. Bell, and Y. R. Boisclair. 2003. Effect of insulin and growth hormone on plasma leptin in the periparturient dairy cow. Am. J. Physiol. Regul. Integr. Comp. Physiol. 285:R1107-R1115. https://doi.org/10.1152/ajpregu .00320 .2003 .
Lochmiller, R. L., and C. Deerenberg. 2000. Trade-offs in evolutionary immunology: Just what is the cost of immunity? Oikos 88:87-98. https://doi.org/10.1034/j.1600-0706.2000.880110.x.

Lohuis, J. A., J. H. Verheijden, C. Burvenich, and A. S. van Miert. 1988. Pathophysiological effects of endotoxins in ruminants. Changes in body temperature and reticulo-rumen motility, and the effect of repeated administration. Vet. Q. 10:109-116. https://doi .org/10.1080/01652176.1988.9694157.

Lu, Y. C., W. C. Yeh, and P. S. Ohashi. 2008. LPS/TLR4 signal transduction pathway. Cytokine 42:145-151. https://doi.org/10.1016/j .cyto.2008.01.006.

Lüttgenau, J., B. Lingemann, O. Wellnitz, A. K. Hankele, M. Schmicke, S. E. Ulbrich, R. M. Bruckmaier, and H. Bollwein. 2016. Repeated intrauterine infusions of lipopolysaccharide alter gene expression and lifespan of the bovine corpus luteum. J. Dairy Sci. 99:66396653. https://doi.org/10.3168/jds.2015-10806.

Magata, F., M. Horiuchi, R. Echizenya, R. Miura, S. Chiba, M. Matsui, A. Miyamoto, Y. Kobayashi, and T. Shimizu. 2014. Lipopolysaccharide in ovarian follicular fluid influences the steroid production in large follicles of dairy cows. Anim. Reprod. Sci. 144:6-13. https://doi.org/10.1016/j.anireprosci.2013.11.005.

Mateus, L., L. Lopes da Costa, P. Diniz, and A. J. Ziecik. 2003. Relationship between endotoxin and prostaglandin (PGE2 and PGFM) concentrations and ovarian function in dairy cows with puerperal endometritis. Anim. Reprod. Sci. 76:143-154. https://doi.org/10 .1016/S0378-4320(02)00248-8.

Matsumura, T., A. Ito, T. Takii, H. Hayashi, and K. Onozaki. 2000 Endotoxin and cytokine regulation of toll-like receptor (TLR) 2 and TLR4 gene expression in murine liver and hepatocytes. J. Interferon Cytokine 20:915-921. https://doi.org/10.1089/ 10799900050163299.

Matsushita, K., R. Motani, T. Sakuta, S. Nagaoka, T. Matsuyama, K. Abeyama, I. Maruyama, H. Takada, and M. Torii. 1999. Lipopolysaccharide enhances the production of vascular endothelial growth factor by human pulp cells in culture. Infect. Immun. 67:1633-1639.

McCord, J. M., and I. Fridovich. 1969. Superoxide dismutase: An enzymic function for erythrocuprein. J. Biol. Chem. 244:6049-6055.

McCracken, V. L., G. Xie, S. E. Deaver, L. H. Baumgard, R. P. Rhoads, and M. L. Rhoads. 2015. Short communication: Hepatic progesterone-metabolizing enzymes cytochrome P450 2C and 3A in lactating cows during thermoneutral and heat stress conditions. J. Dairy Sci. 98:3152-3157. https://doi.org/10.3168/jds.2014-8826.

Moriya, N., H. Kataoka, H. Fujino, J. Nishikawa, and F. Kugawa. 2014. Different expression patterns of hepatic cytochrome P450s during anaphylactic or lipopolysaccharide-induced inflammation. Pharmazie 69:142-147. https://doi.org/10.1691/ph.2014.3725.

Moyes, K. M., T. Larsen, P. Sørensen, and K. L. Ingvartsen. 2014. Changes in various metabolic parameters in blood and milk during experimental Escherichia coli mastitis for primiparous Holstein dairy cows during early lactation. J. Anim. Sci. Biotechnol. 5:47. https://doi.org/10.1186/2049-1891-5-47.

Munford, R. S., and C. L. Hall. 1986. Detoxification of bacterial lipopolysaccharides (endotoxins) by a human neutrophil enzyme. Science 234:203-205.

Nathan, C. 2006. Neutrophils and immunity: Challenges and opportunities. Nat. Rev. Immunol. 6:173-182. https://doi.org/10.1038/ nri1785.

NRC. 2001. Nutrient Requirements of Dairy Cattle. 7th rev. ed. Natl. Acad. Press, Washington, DC.

Newby, N. C., K. E. Leslie, H. D. Putnam Dingwell, D. F. Kelton, D. M. Weary, L. Neuder, S. T. Millman, and T. F. Duffield. 2017. The effects of periparturient administration of flunixin meglumine on the health and production of dairy cattle. J. Dairy Sci. 100:582587. https://doi.org/10.3168/jds.2016-11747.

Newby, N. C., D. Renaud, R. Tremblay, and T. F. Duffield. 2014. Evaluation of the effects of treating dairy cows with meloxicam at calving on retained fetal membranes risk. Can. Vet. J. 55:11961199.

Perry, G. A., and B. L. Perry. 2008. Effect of preovulatory concentrations of estradiol and initiation of standing estrus on uterine $\mathrm{pH}$ 
in beef cows. Domest. Anim. Endocrinol. 34:333-338. https://doi .org/10.1016/j.domaniend.2007.09.003.

Peter, A. T., J. E. Simon, C. W. Luker, and W. T. K. Bosu. 1990. Site of action for endotoxin-induced cortisol release in the suppression of preovulatory luteinizing hormone surges. Theriogenology 33:637-643. https://doi.org/10.1016/0093-691X(90)90540-A.

Plessers, E., H. Wyns, A. Watteyn, B. Pardon, P. De Backer, and S. Croubels. 2015. Characterization of an intravenous lipopolysaccharide inflammation model in calves with respect to the acutephase response. Vet. Immunol. Immunopathol. 163:46-56. https:/ /doi.org/10.1016/j.vetimm.2014.11.005.

Richards, J. S., Z. Liu, and M. Shimada. 2008. Immune-like mechanisms in ovulation. Trends Endocrinol. Metab. 19:191-196. https: //doi.org/10.1016/j.tem.2008.03.001.

Rietschel, E. T., T. Kirikae, F. U. Schade, U. Mamat, G. Schmidt, H. Loppnow, A. J. Ulmer, U. Zahringer, U. Seydel, F. Di Padova, M. Schreier, and H. Brade. 1994. Bacterial endotoxin: Molecular relationships of structure to activity and function. FASEB J. $8: 217-225$.

Schroedl, W., B. Fuerll, P. Reinhold, M. Krueger, and C. Schuett 2001. A novel acute phase marker in cattle: Lipopolysaccharide binding protein (LBP). J. Endotoxin Res. 7:49-52.

Seemann, S., F. Zohles, and A. Lupp. 2017. Comprehensive comparison of three different animal models for systemic inflammation. J. Biomed. Sci. 24:60. https://doi.org/10.1186/s12929-017-0370-8.

Sheldon, I. M., J. Cronin, L. Goetze, G. Donofrio, and H. J. Schuberth. 2009. Defining postpartum uterine disease and the mechanisms of infection and immunity in the female reproductive tract in cattle. Biol. Reprod. 81:1025-1032. https://doi.org/10.1095/biolreprod .109 .077370

Sheldon, I. M., J. G. Cronin, G. D. Healey, C. Gabler, W. Heuwieser, D. Streyl, J. J. Bromfield, A. Miyamoto, C. Fergani, and H. Dobson. 2014. Innate immunity and inflammation of the bovine female reproductive tract in health and disease. Reproduction 148:R41R51. https://doi.org/10.1530/REP-14-0163.

Sheldon, I. M., D. E. Noakes, A. N. Rycroft, D. U. Pfeiffer, and H. Dobson. 2002. Influence of uterine bacterial contamination after parturition on ovarian dominant follicle selection and follicle growth and function in cattle. Reproduction 123:837-845.

Shimizu, T., K. Miyauchi, K. Shirasuna, H. Bollwein, F. Magata, C. Murayama, and A. Miyamoto. 2012. Effects of lipopolysaccharide (LPS) and peptidoglycan (PGN) on estradiol production in bovine granulosa cells from small and large follicles. Toxicol. In Vitro 26:1134-1142. https://doi.org/10.1016/j.tiv.2012.06.014.

Shuster, D. E., R. J. Harmon, J. A. Jackson, and R. W. Hemken. 1991. Reduced lactational performance following intravenous endotoxin administration to dairy cows. J. Dairy Sci. 74:3407-3411. https:// doi.org/10.3168/jds.S0022-0302(91)78530-5.

Silván, G., J. C. Illera, and M. Illera. 1993. Development and validation of competitive ELISA to determine follicular fluid progesterone concentrations. Theriogenology 39:677-689. https://doi.org/ 10.1016/0093-691X(93)90253-2.

Skarnes, R. C., and M. J. K. Harper. 1972. Relationship between endotoxin-induced abortion and the synthesis of prostaglandin F. Prostaglandins 1:191-203. https://doi.org/10.1016/0090 -6980(72)90004-4.

Song, W. C. 2001. Biochemistry and reproductive endocrinology of estrogen sulfotransferase. Ann. N. Y. Acad. Sci. 948:43-50. https: //doi.org/10.1111/j.1749-6632.2001.tb03985.x.
Strandberg, Y., C. Gray, T. Vuocolo, L. Donaldson, M. Broadway, and R. Tellam. 2005. Lipopolysaccharide and lipoteichoic acid induce different innate immune responses in bovine mammary epithelial cells. Cytokine 31:72-86. https://doi.org/10.1016/j.cyto.2005.02 .010 .

Strnad, P., F. Tacke, A. Koch, and C. Trautwein. 2017. Liver-Guardian, modifier and target of sepsis. Nat. Rev. Gastroenterol. Hepatol. 14:55-66. https://doi.org/10.1038/nrgastro.2016.168.

Suojala, L., T. Orro, H. Järvinen, J. Saatsi, and S. Pyörälä. 2008 Acute phase response in two consecutive experimentally induced E. coli intramammary infections in dairy cows. Acta Vet. Scand. 50. https://doi.org/10.1186/1751-0147-50-18.

Suzuki, C., K. Yoshioka, S. Iwamura, and H. Hirose. 2001. Endotoxin induces delayed ovulation following endocrine aberration during the proestrous phase in Holstein heifers. Domest. Anim. Endocrinol. 20:267-278. https://doi.org/10.1016/S0739-7240(01)00098-4.

Taudorf, S., K. S. Krabbe, R. M. Berg, B. K. Pedersen, and K. Møller. 2007. Human models of low-grade inflammation: Bolus versus continuous infusion of endotoxin. Clin. Vaccine Immunol. 14:250-255. https://doi.org/10.1128/CVI.00380-06.

Tuo, W., T. L. Ott, S. H. Liu, and F. W. Bazer. 1999. Intrauterine infusion of bacterial lipopolysaccharide (LPS) prior to mating has no adverse effect on fertility, fetal survival and fetal development. J. Reprod. Immunol. 42:31-39.

Waldron, M. R., A. E. Kulick, A. W. Bell, and T. R. Overton. 2006. Acute experimental mastitis is not causal toward the development of energy-related metabolic disorders in early postpartum dairy cows. J. Dairy Sci. 89:596-610. https://doi.org/10.3168/jds.S0022 -0302(06)72123-3.

Waldron, M. R., T. Nishida, B. J. Nonnecke, and T. R. Overton. 2003. Effect of lipopolysaccharide on indices of peripheral and hepatic metabolism in lactating cows. J. Dairy Sci. 86:3447-3459. https:// doi.org/10.3168/jds.S0022-0302(03)73949-6.

Weisiger, R. A., and I. Fridovich. 1973. Superoxide dismutase. Organelle specificity. J. Biol. Chem. 248:3582-3592.

West, M. A., and W. Heagy. 2002. Endotoxin tolerance: A review. Crit. Care Med. 30:S64-S73

Wheelock, J. B., R. P. Rhoads, M. J. Vanbaale, S. R. Sanders, and L. H. Baumgard. 2010. Effects of heat stress on energetic metabolism in lactating Holstein cows. J. Dairy Sci. 93:644-655. https://doi .org/10.3168/jds.2009-2295.

Williams, E. J., K. Sibley, A. N. Miller, E. A. Lane, J. Fishwick, D. M. Nash, S. Herath, G. C. W. England, H. Dobson, and I. M. Sheldon. 2008. The effect of Escherichia coli lipopolysaccharide and tumour necrosis factor alpha on ovarian function. Am. J. Reprod. Immunol. 60:462-473.

Xie, G., L. C. Cole, L. D. Zhao, M. V. Skrzypek, S. R. Sanders, M. L. Rhoads, L. H. Baumgard, and R. P. Rhoads. 2016. Skeletal muscle and hepatic insulin responsiveness is maintained in heat-stressed lactating Holstein cows. J. Dairy Sci. 99:4032-4042. https://doi .org/10.3168/jds.2015-10464.

Yan, J., S. Li, and S. Li. 2014. The role of the liver in sepsis. Int. Rev. Immunol. 33:498-510. https://doi.org/10.3109/08830185.2014 .889129 .

Zebeli, Q., and B. N. Ametaj. 2009. Relationships between rumen lipopolysaccharide and mediators of inflammatory response with milk fat production and efficiency in dairy cows. J. Dairy Sci. 92:3800-3809. https://doi.org/10.3168/jds.2009-2178. 